\title{
加圧式床吹出し居住域空調方式の床吹出し口の特性に関する研究 STUDY ON THE CHARACTERISTICS OF FLOOR OUTLET OF PRESSURIZED UNDER FLOOR AIR-CONDITIONING SYSTEM FOR OCCUPIED ZONE
}

\author{
平山昌宏* \\ Masahiro HIRA YAMA
}

\begin{abstract}
For correct estimation of the vertical air temperature distribution with the pressurized under floor air-conditioning system for occupied zone during cooling operation, the air discharge angle of the twisted-groove type $200 \phi$ floor-outlet, air leakage through access-floor, and the temperature difference between supply and return, were taken as the most influential factors on the vertical temperature distribution. A special chart is presented to set up the control target for those three factors so as to give thermal comfort within the occupied zone. It was clarified that newly devised shutter of the floor outlet for this system would not change the discharge air velocity by manual operation of occupants, and thus the height reached by the discharged air would not vary.
\end{abstract}

Keywords : under floor air conditioning, floor outlet, vertical temperature distribution. thermal comfort、 occupied zone、 access floor 㦿吹出し空調、床吹出し口、垂直温度分布、熱的快適性、居住域、二重床

\section{1.はじめに}

休吹出し空調方式は冷房運転時に効率的で快適な居住域空調を行 うことができ、特に機能的な事務室などではレイアウト変更への対 応が容易で、パーソナル的空調が可能であるとのことから、近年わ が国でも適用例が增しつつある。

しかし、床吹出し空調方式が広く普及しているドイツやイギリス をはじめ、我国で用いられている多くの床吹出し口の機能は必ずし も十分なものでなかった。それらの気流特性は冷暖房兼用を想定し たものと考えられ、わが国でも1988 年から床吹出し空調方式が 事務室に採用され始めたが、熱負荷密度が高く冷房要求から機器仕 様が決まることが多い日本の事務室などには適したものではなく、 冷房運転時には居住域垂直温度差が大きくなり、快適な空調が実現 したとはいえない状況であった。

また、休吹出し空調方式は天井方式と異なって、空調空気が床面 から供給されることから各種の論議がある。それらは穈埃濃度や垂 直温度分布、気流感などに関する問題、さらに床面各所から空調空 気が供給されることからの熱的快適性や二重床内の蓄熱、換気効率 などへの評価法などがあり、さらにパーテションなど什器利用の空 調方式の提案などもある。

この様に床吹出し空調方式は、従来の天井方式と異なった特性を
持つことから、目的によりその特徴を生かす各種の方式が考えられ ている。

そこで、日本の機能的事務室に用いられるための床吹出し空調方 式の条件を次のように考えた。

想定する機能的事務室は、二重床が用いられてOA機器用の比較 的大きな熱負荷があり、熱負荷密度が異なるワークスペースを利用 することが多く、レイアウト変更も多い。床吹出し空調方式として 求められることは、OA機器などの熱負荷の大小による影響を受け にくいことや、各人の好みに応じてパーソナル的に制御できること、 さらに冷房運転時に $2.5 \mathrm{~m}$ 程度の天井高でも熱的快適性を満たした居 住域空調を行えること、経済的であることなどである。

この様な条件に基づいたシステム構成と問題点を考えると、第 1 の課題は、経済性から最小の循盽空気量が求められることによる居 住域の垂直温度差であり、第 2 に近傍から吹出される気流の制御で あると考えた。

そこで、経済性や制御性を考虑して加圧式とし、実験や実測によ り居住域の垂直温度差に影響を及ぼす要因やその状況を把握し、シ ステム機器類などの最適な特性を求めていくことにした。

実験や実測を進めていく間に、各種旋回流形床吹出し口の中でも 淟形のものが吹出し機構が簡単で気流形状が素直でわかりやすいこ 
と、加圧式では二重床からの漏気量が以外に多いこと、さらに吹出 し温度差が気流の到達高さに大きな影響があることなどがわかって きた。

この様なことから、加圧式床吹出し居住域空調方式（以降、本空 調方式と称す）の垂直温度差に影響を及ぼす大きな要因を、床吹出 し口の気流特性と二重床からの漏気率、供給温度差の 3 要因に限定 し、それら相互に関連する制御目標值を実験や実測などから推定す ることにした。

気流制御については、従来の床吹出し口付属の風量調節シャッタ 一は、本来の目的が二重床下チャンバーの圧力調整用であるが、実 際には各人のパーソナルな気流調整用として用いられている かし、このシャッターを操作する（絞る）と床吹出しロから吹出さ れる気流速度が小さくなり、気流が所定の高くまで到達しなくなっ て、床吹出し空調方式の長所であるパーソナル性が全体の垂直温度 分布を悪化させる原因にもなっていた。

そこで、各人が自在に操作しても吹出される気流速度に影響しな い床吹出しロシャッターを考案し、その特性を調べることにした。

\section{2.用語や記号など}

次に特徵的な用語や記号などを示す。

吹出し温度差 $\quad: \Delta \mathrm{t} \quad$ : 吹出し空気と吹出し気流到達高さ における室温との温度差

居住域垂直温度差 : $\Delta \mathrm{t} \mathrm{h}$ : 床上 $1.7 \mathrm{~m}$ と0.1mとの温度差 供給温度差 $\quad: \Delta \mathrm{t} \mathrm{SR}$ : 吹出し温度と還気温度との温度差 垂直温度分布 : 室内温度の垂直方向の温度分布 垂直温度差 室内の某高さと他の高さとの温度 差

\section{3 . 床吹出し空調方式の冷房時の熱的快適性の条件}

朱吹出し空調方式で冷房時に熱的快適性に影響を与える項目とし ては次の 2 つが考えられ、その目標值を表 1 に示す1) ${ }^{13}$ 。

(1)居住域での垂直温度差

(2)居住域でのドラフト

\section{1 居住域垂直温度差}

\section{1 ． 1 居住域垂直温度差を制御する条件}

休吹出し空調方式における冷房時の居住域垂直温度差 $\Delta \mathrm{th}$ 学小 さくするには循睘空気量を大きくすれば容易であるが装置容量が大 きくなる。そこで、天井吹出し方式と同等の循睘空気量という条件 で、 $\Delta \mathrm{th}$ h許容される範囲に制御できるようにする。

\section{1．2 居住域垂直温度差に影響を与える要因}

本空調方式で $\Delta \mathrm{th}$ に影響する要因は、予備実験などから次の 3

つと考えられ、これらには互いに関係があると推測された。

(1)吹出し気流特性は、その到達高さが空調域高さを左右し、室内空 気との混合性や床面での誘引性などが垂直温度分布に影響する (2)二重㦿から漏気する空調空気は想像以上に多く、床吹出しロから のものと合成された気流で空調がなされる。従って、床吹出しロ の気流特性を評価するにも、二重床からの漏気率を把握し、必要 に応じて制御する必要がある

(3)供給温度差は、垂直非等温吹出し時の吹出し気流の到達高さに影 響し、その到達高さは吹出し速度と温度差によるアルキメデス数

\section{表 1 ．事務室の温熱環境の目標値}

\begin{tabular}{|c|c|c|}
\hline 項 & 一般的目摆 & 本研究での目櫕 \\
\hline $\begin{array}{l}\text { 居住城垂直温度差 } \\
\text { (本上 } 1.7 \text { と } 0.1 \mathrm{~m})\end{array}$ & $\begin{array}{r}\text { ASHRAE 55-81では } \\
3^{\circ} \mathrm{CW下}\end{array}$ & 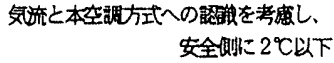 \\
\hline 気流束度 & 一般的には $0.25 \mathrm{~m} / \mathrm{s}$ 以下 & $\begin{array}{r}\text { 居住城に近い本空調方式の特数を考喓 } \\
\text { して安全側に0. } 2 \mathrm{~m} / \mathrm{s} \text { 以下 }\end{array}$ \\
\hline
\end{tabular}

表2、機能的な事務室のインテリアエリアの熱負荷の想定と空調空気供給量

\begin{tabular}{|c|c|c|}
\hline 項 & 内容。考え方 & 鶖負做の想定 \\
\hline 人員䜿度 & 作域 $0.2 N \mathrm{~m}^{\prime}$ & $12 \mathrm{~W} / \mathrm{m}^{2}$ \\
\hline 天井照明 & $500 \mathrm{LX} \sim 600 \mathrm{Lx}$ & $\begin{array}{c}15 \sim 36 \mathrm{w} / \mathrm{m} \\
\text { ルーパの有無、モジュールから }\end{array}$ \\
\hline \multirow[t]{2}{*}{ 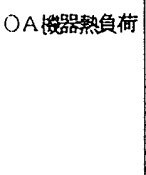 } & 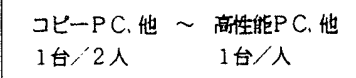 & $25 \sim 45 \mathrm{w} / \mathrm{m}$ \\
\hline & $\begin{array}{c}\text { 設司室などでは高性能EWS, 他 } \\
1 \sim 2 \text { 台/人 }\end{array}$ & $75 \sim 100 \mathrm{~W} / \mathrm{m}$ \\
\hline 閒仕切の綮負徛 & 奥行きの広い室〜 虬室 & $5 \sim 10 \mathrm{~W} / \mathrm{m}^{\prime}$ \\
\hline \multirow{2}{*}{ 合的整負倚 } & 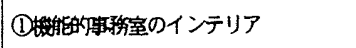 & $60 \sim 100 \mathrm{~W} / \mathrm{m}$ \\
\hline & (2)設社室など & $115 \sim 150 \mathrm{~W} / \mathrm{m}$ \\
\hline \multirow{2}{*}{ 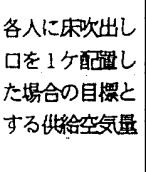 } & $\begin{array}{l}\text { (3) } \\
\text { (1)より) }\end{array}$ & 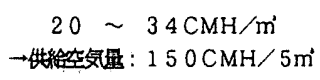 \\
\hline & $\begin{array}{l}\text { (4)設检室など } \\
\text { (2)より) }\end{array}$ & 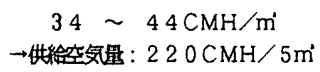 \\
\hline
\end{tabular}

表3．麻パネルと栨出し口寸法

\begin{tabular}{|c|c|c|}
\hline \multirow{3}{*}{ 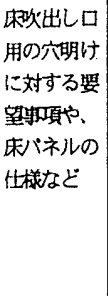 } & $\begin{array}{l}\text { 日本の和敄室 } \\
\text { での汎用的な } \\
\text { 二重床 }\end{array}$ & 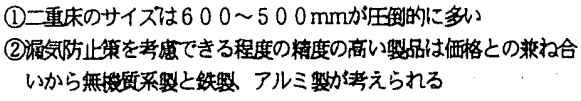 \\
\hline & $\begin{array}{l}\text { 床バネルの } \\
\text { 恃様 }\end{array}$ & 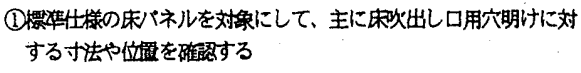 \\
\hline & $\begin{array}{l}\text { 本欦出し口 } \\
\text { の配顐 }\end{array}$ & 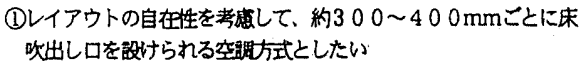 \\
\hline \multirow{2}{*}{$\begin{array}{l}\text { 二重床のパ } \\
\text { ネル䟻度の } \\
\text { からの制約 } \\
\text { など }\end{array}$} & $\begin{array}{r}600 \mathrm{~mm} \text { 角 } \\
\text { 床バネル }\end{array}$ & 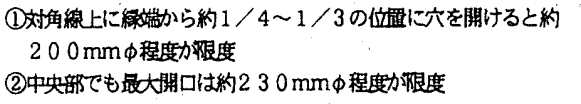 \\
\hline & $\begin{array}{r}500 \mathrm{~mm} \text { 角 } \\
\text { 本バネル }\end{array}$ & 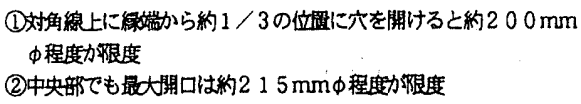 \\
\hline
\end{tabular}

に依存はするものと仮定する

3. 2 居住域でのドラフト

居住域でのドラフトは吹出される空調空気が居住者に不快感を与 えるか否かである。

吹出し気流が目標とする速度まで減衰するのに必要な距離は、座 席位置と床吹出し口との必要な離隔距離に影響する。日本の機能的 な事務室の什器や通路幅などを考慮すると約0.8m以下となることが 望ましいと考えた。

通路などでは、床吹出し口直上の気流速度が極端に早くなければよ いと考えた。 


\section{4. 床吹出し口に関する条件}

床吹出しロへの要求機能や設置条件などを理解するために、機能 的な事務室の熱負荷やレイアウト状況を表 2 のように想定し、要求 される吹出し空気量や二重床パネルなどに関する制約条件をまとめ、 試作品や市販品についてその状況を実験により確かめた。

\section{1. 床吹出し口の吹出し空気量と外形寸法}

(1)吹出し空気量は、表 2 から必要空調空気供給量を $20 \sim 34 \mathrm{C} \mathrm{MH/}$ $\mathrm{m}^{2}$ として、1ケ当たり $150 \mathrm{CMH}$ 程度とした。

設計室などでは熱負荷に応じて複数を用いることとした。 (2)外形寸法は、最も多く利用されている500、600 $\mathrm{mm}$ 角の床パネル 強度や、レイアウトを考慮した配置から表 3 に示すように外形は 最大 $200 \mathrm{~mm} \phi$ 程度とした

\section{2 二重床からの漏気}

二重床からの漏気は何らかの制御をする必要があるが、その目標 值は実験や実測結果により判断することとした。

\section{3 市販品などの床吹出し口の特性}

試作品を含む多くの市販品の性能を予備実験で主に可視化により 評価した結果、溝形 $200 \mathrm{~mm} \phi$ 旋回流式で吹出し角度 30 度（鈶直線 からの傾き角度）の某市販品（以降、この形式を床吹出し口A と称 し、吹出し角度を末尾に表す。EX. A 30など）を吹出し空気量的 $130 \sim 150 \mathrm{CMH} /$ ケで吹出した状況（11〜15 Pa）が、気流分布や 外形寸法、意匠性などの評価から良好と判断された。しかし、吹出 し気流到達高さは不足ぎみで、評価基準である $\Delta \mathrm{th}$ h力゙きい傾向

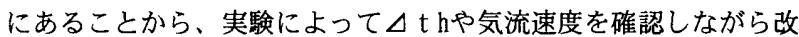
良していくことにした。

但し、床下と室内との差圧については二重床からの漏気への配慮 から20 Pa以下を前提にした。

\section{5. 実験および実測}

本空調方式の特性を詳細に把握するために 5 種類の実験と 4 箇所 の事務室での実測を行った。その実験および実測の概要を表 4 に示 す。

図 1 に実測 1 の平面図を、図 2 に実験 5 の平面図と主に実測した 位置とを示す。事務室における実測では、使用者の許しを得て設定 室温や吹出し温度、林吹出し口の設置個数、位置などを調整して測 定した。

5. 1 吹出し角度などによる垂直温度分布

5. 1.1 吹出し口の形状. 寸法

実験では各種の床吹出し口を用いたが、実測では溝形 $200 \mathrm{~mm} \phi$ 旋回流の床吹出しロAを用いた。床吹出しロA18は吹出し角度が18 度で、林吹出し口A 30 と吹出し角度のみが異なる。床吹出し口Bは 溝形旋回流形で角度も A 30 と同じ 30 度であるが、吹出し断面形状の 一部に屈折があることや、外形寸法も $185 \mathrm{~mm} \phi$ とやや小さい。写 真 1 に床吹出し口A18の外観を示す。

\section{1．2 吹出し角度などと気流形状}

図 3 に床吹出し口A 30、A 18、Bのほぼ標準的差圧により吹出さ れた場合の気流形状を示す。吹出し温度差はそれぞれ多少異なるが、 吹出し気流形状については、A 30 とA18 とでは吹出し角度の違いに よる気流到達高さが異なり、A 30 と B とでは同じ 30 度でも断面形状 や寸法の違いが吹出し気流の到達高さに影響していることがわかる。

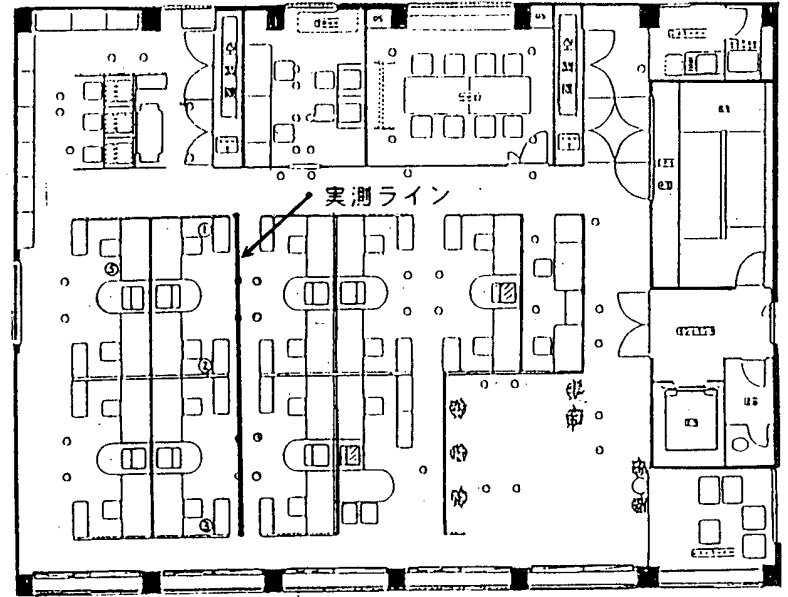

図. 1 実測 2 の平面図と実測位置 (有効 $270 \mathrm{~m}$ 。天井高 $2.7 \sim 3.0 \mathrm{~m}$ )

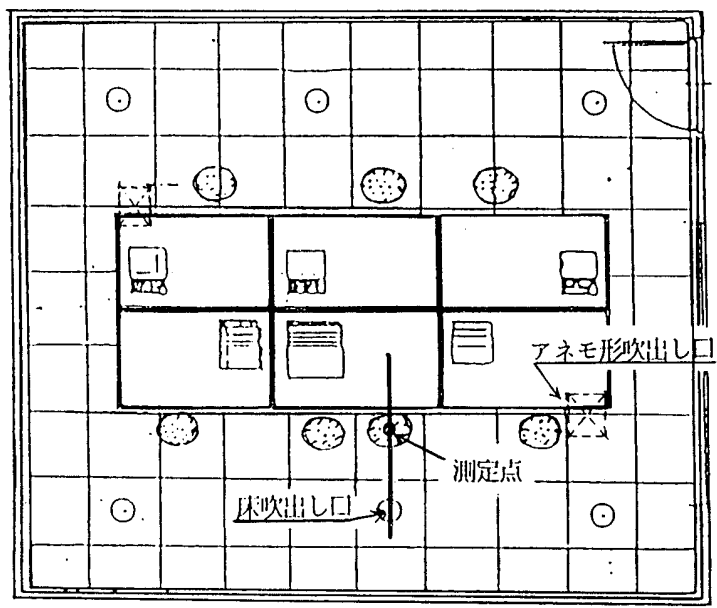

図. 2 実験 5 の実験室

$(5.0 \times 6.0 \mathrm{~m}$ 。天井高 $2.7 \mathrm{~m}$ )

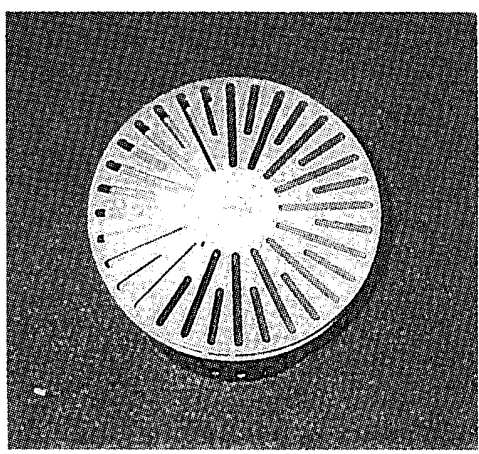

写真. 1 床吹出しロA 18

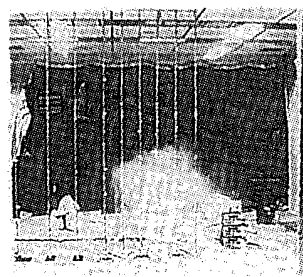

床吹出し口A 30

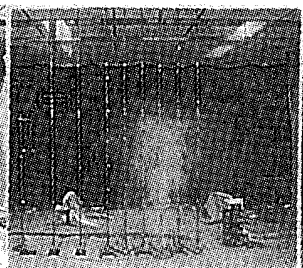

床吹出し口 A 18

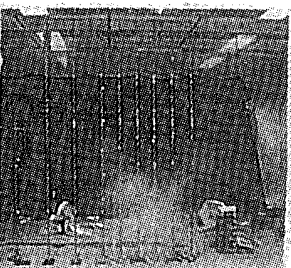

床吹出しロ 8

$14 \mathrm{~Pa}, \Delta \mathrm{t}=4.9{ }^{\circ} \mathrm{C} \quad 14 \mathrm{~Pa}, \Delta \mathrm{t}=5.9^{\circ} \mathrm{C} \quad 18 \mathrm{~Pa}, \Delta \mathrm{t}=6.1{ }^{\circ} \mathrm{C}$ 図. 3 実験室 5 の 気流形状 


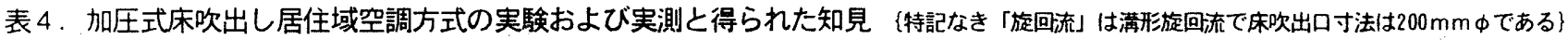

\begin{tabular}{|c|c|c|c|c|c|c|c|c|c|c|c|c|}
\hline & \multirow{3}{*}{$\begin{array}{c}\text { 実験や実測 } \\
\text { の } \\
\text { 目 }\end{array}$} & \multirow{3}{*}{\multicolumn{2}{|c|}{ 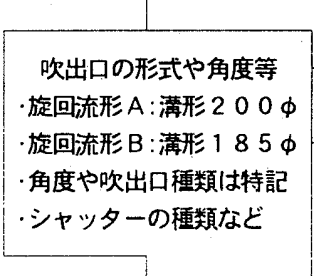 }} & \multirow{2}{*}{\multicolumn{2}{|c|}{$\begin{array}{l}\text { 主 な 実 } \\
\text { 供給温度差 }\end{array}$}} & \multirow{3}{*}{$\begin{array}{l}\text { 硢 条 件 } \\
\begin{array}{|l|}\text { OA機器や } \\
\text { 負荷率。 } \\
\text { 人体熱発熱 } \\
\text { など }\end{array}\end{array}$} & \multicolumn{2}{|c|}{ 及 及 ひ 内容 } & \multirow{3}{*}{$\begin{array}{c}\text { 得 ら れ } \\
\text { ·满形 } 200 \text { 申旋回流式 } \\
\text { の吹出し角度と気流到 } \\
\text { 逢高さなどに対して } \\
\text { ·他の吹出し口に対して }\end{array}$} & \multirow{3}{*}{$\begin{array}{l}\text { た 知 } \\
\mid \begin{array}{l}\text { 二重 } \\
\text { 床の } \\
\text { 種類 } \\
\text { と漏 } \\
\text { 気量 }\end{array}\end{array}$} & \multirow{3}{*}{ 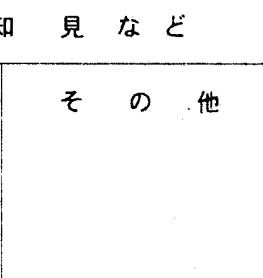 } \\
\hline & & & & & & & & & その他 & & & \\
\hline & & & & & $\mid \begin{array}{l}\text { 設計 } \\
\text { 值 } \\
{ }^{\circ} \mathrm{C}\end{array}$ & $\mid$\begin{tabular}{c|} 
実澌 \\
時: \\
${ }^{\circ} \mathrm{C}$
\end{tabular} & & $\begin{array}{l}\text { 面棈自 } \\
\text { 二重床 } \\
\text { の漏気 } \\
\text { 率等\% }\end{array}$ & & & & \\
\hline & $\begin{array}{c}\text { 実 } \\
\text { 験 } \\
1\end{array}$ & $\begin{array}{l}\text { ·簡易な実験で、 } \\
\text { の吹出し口種類や } \\
\text { よる吹出し気流开 } \\
\text { 直温度分布の違し } \\
\cdot \text { 人の動きによるる }\end{array}$ & $\begin{array}{l}\text { 润吹出し時 } \\
\text { 角度などに } \\
\text { 状や室内垂 } \\
\text { を見る } \\
\text { 否を知る }\end{array}$ & $\begin{array}{l}\text { 旋回流形 } A \\
15 \sim 60 \text { 度 } \\
\text { 丸形リング式 } \\
\text { 軸流形 } \\
4 \text { 分割旋回流 }\end{array}$ & - & $\begin{array}{c}3 \\
\sim \\
5\end{array}$ & 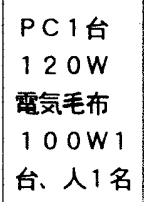 & $\begin{array}{c}10 \mathrm{~m} \\
\text { 漏気 } \\
\text { なし }\end{array}$ & $\begin{array}{l}\text { 人の步行 } \\
\text { の有無に } \\
\text { よる } \\
\text { 影䇾度 }\end{array}$ & \begin{tabular}{|l|} 
(1)满形旋回流形で15 20 \\
度の角度が好ましい \\
(2)軸流は比較的良好 \\
(3)丸形リング式は一部吹 \\
出し気流の乱れあり
\end{tabular} & $\begin{array}{c}\text { 漏気 } \\
\text { なし } \\
\end{array}$ & 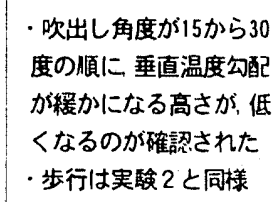 \\
\hline 実 & $\begin{array}{c}\text { 実 } \\
\text { 験 } \\
2\end{array}$ & $\begin{array}{l}\text { ·より実際の事務 } \\
\text { 室で、実験 } 1 \text { て女 } \\
\text { とされた吹出し口 } \\
\text { 況を確認する }\end{array}$ & $\begin{array}{l}\text { 至に近い実験 } \\
\text { ましい角度 } \\
1 \text { ケでの状 }\end{array}$ & \begin{tabular}{|c|} 
旋回流形 $\mathrm{A}$ \\
15.18. \\
20.25. \\
30 度 \\
を 1 ヶ
\end{tabular} & - & $\left|\begin{array}{c}3 \\
\sim \\
1\end{array}\right|$ & $\begin{array}{l}\text { 電気ヒータ } \\
\text { (約 } 35 \mathrm{~K}) \\
\text { を椅上に } \\
\text { 還気温度に } \\
\text { 応して制御 }\end{array}$ & $\begin{array}{l}19 \mathrm{~m} \\
\text { 漏気 } \\
\text { なし }\end{array}$ & $\begin{array}{l}6 \text { 面サン } \\
\text { トイイッチ } \\
\text { パネル。 } \\
\text { 模擬熱負 } \\
\text { 何。歩行 }\end{array}$ & $\begin{array}{l}\text { (1)15度は } \Delta \mathrm{t} \text { が小だとす } \\
\text { ぐ井に届いてしまう } \\
\text { (2)18度は } 2 \mathrm{~m} \text { を超える程 } \\
\text { 度で最も好ましい } \\
\text { (3)20度は高さが不足きみみ }\end{array}$ & $\begin{array}{l}\text { 漏気 } \\
\text { なし }\end{array}$ & 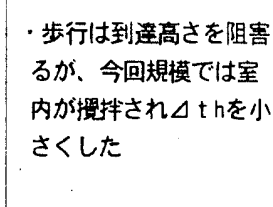 \\
\hline & $\begin{array}{c}\text { 寒 } \\
\text { 験 } \\
3\end{array}$ & $\begin{array}{l}\text { ·実験 } 2 \text { の延長で } \\
\text { で.より最適な角 } \\
\text { ·熱負荷や循環空 } \\
\text { 同水準に. 漏気量 }\end{array}$ & $\begin{array}{l}\text { 次出しロ } 2 \text { } \\
\text { 度を絞込む: } \\
\text { 気楅を実際と } \\
\text { も变えて行う }\end{array}$ & \begin{tabular}{|c} 
旋回流形 $A$ \\
18.20. \\
30 度を \\
$\quad$ 各 2 ケ
\end{tabular} & - & $\begin{array}{c}6 \\
\sim \\
9\end{array}$ & 同上 & $\begin{array}{l}\text { 同上 } \\
\text { 漏気 } \\
0 \sim \\
50 \%\end{array}$ & \begin{tabular}{|c|} 
循環空気 \\
量 5 回 $/ h$ \\
漏気の \\
可視化
\end{tabular} & $\begin{array}{l}\text { (1)18度は最も好ましいと } \\
\text { 判断された }\end{array}$ & $\begin{array}{l}\text { 漏気 } \\
\text { を強 } \\
\text { 制的 } \\
\text { 制御 }\end{array}$ & $\begin{array}{l}\text { (1)同じ床吹出口でも漏気 } \\
\text { 率により } \mathrm{thが大き} \\
\text { 異なることを確認 } \\
\text { (2)漏気空気は床面に漂う }\end{array}$ \\
\hline & $\begin{array}{l}\text { 实 } \\
\text { 験 } \\
4\end{array}$ & $\begin{array}{l}\text { ・ヘテデスタル式 } \\
\text { 二重床を考案す } \\
\text { 簡易で信頼性力 } \\
\text { ·市販品の漏気 }\end{array}$ & 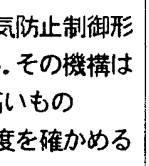 & $\begin{array}{l}\text { (1)本空調方式。 } \\
\text { を考慮して } \\
\text { 摽を } \Delta \mathrm{th} \\
\text { (2)防止制御方伍 }\end{array}$ & $\begin{array}{l}\text { 刀特長て } \\
1 \text { 对 } 1 \text { 工 } \\
\text { 状況か }\end{array}$ & $\begin{array}{l}\text { である } \\
\text { 式二重 } \\
\text { らら連転 }\end{array}$ & ソナル & $レ \neq:$ & $\begin{array}{l}\text { ティ } \\
\text { 御目 } \\
\text { ナる } \\
\text { する }\end{array}$ & $\begin{array}{l}\text { (1)漏気防止方法は信頼性か } \\
\text { シール(パッキンなど) } \\
\text { (2)漏気許容量は施工棈度を } \\
\text { 安全率を見込む }\end{array}$ & とする & $\begin{array}{l}\text { トリンガー利用の上下方向 } \\
\text { る } \\
\text { んで、試験装置では十分な }\end{array}$ \\
\hline & \begin{tabular}{|c|} 
实 \\
験 \\
5
\end{tabular} & 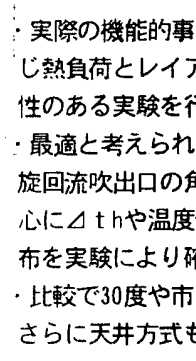 & 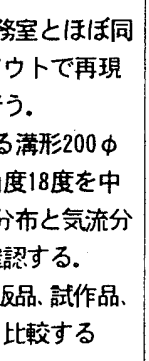 & $\begin{array}{c}\text { 旋回流形 } \mathrm{A} \\
18.30 \text { 度 } \\
\text { 旋回流形 } \mathrm{B} \\
30 \text { 度 } \\
\text { 軸流式 } 15 \text { 度 } \\
\text { スロット式 } \\
\text { 丸形リング式 } \\
\text { 天井吹出方式 }\end{array}$ & - & $\stackrel{5}{\sim}$ & $\begin{array}{r}\text { OA機器 } \\
34 \sim 28 \\
W / \mathrm{m}^{\prime} \\
E W S \times 1 \\
P C \times 5 \\
\text { 人体は5 } 0 \\
\text { Wの雷気毛 } \\
\text { 布を掎子に } \\
\text { 掛けた }\end{array}$ & $\begin{array}{c}30 \mathrm{~m}^{2} \\
\\
\text { 漏気制 } \\
\text { 御形。 } \\
\text { 漏気率 } \\
10 \sim \\
60 \\
\%\end{array}$ & $\begin{array}{l}\text { 吹出しロ } \\
\text { 形式や角 } \\
\text { 度、差圧 } \\
\text { による重 } \\
\text { 直温度差 } \\
\text { を比較確 } \\
\text { 認。天开 } \\
\text { 方式との } \\
\text { 比較も }\end{array}$ & 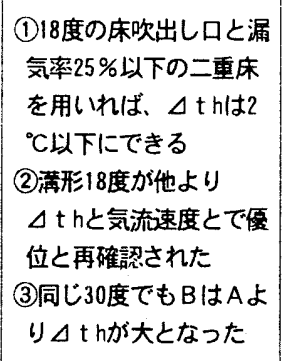 & 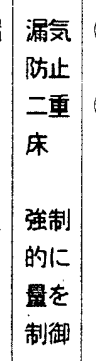 & $\begin{array}{l}\text { (1)二重床からの漏気防止 } \\
\text { 制御の必要かかかった } \\
\text { (2)天井方式より3K高い } \\
\text { 給気でもほほほ同し居住 } \\
\text { 域温度が得られ、両方 } \\
\text { 式の温度形成の違いか } \\
\text { 確認できた }\end{array}$ \\
\hline 実 & $\begin{array}{c}\text { 実 } \\
\text { 蹪 } \\
1\end{array}$ & $\begin{array}{l}\text { ·熱負荷が大きい } \\
\text { 事務室の例として } \\
\text { や吹出し角度なと } \\
\text { う。 } \\
\text { ·多少憬間風の影 }\end{array}$ & $\begin{array}{l}\text { 奉際の機能的 } \\
\text { 供給温度差 } \\
\text { を変えて行 } \\
\text { 祭があった。 }\end{array}$ & \begin{tabular}{|l} 
旋回流形A \\
18.30 度 \\
$100 \%$ 促来 \\
形シャッター \\
付
\end{tabular} & 10 & $\begin{array}{l}5 \\
\sim \\
9\end{array}$ & 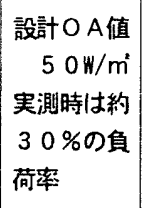 & $\begin{array}{r}270 \\
m \\
\text { m } \\
\text { 漏気率 } \\
25 \sim \\
40 \%\end{array}$ & \begin{tabular}{|l|} 
中熱負荷 \\
事務室。 \\
出入口は \\
外気状態
\end{tabular} & $\begin{array}{l}\text { (1) } \Delta \mathrm{th} \text { h } \Delta \mathrm{t} \text { がほほ同 } \\
\text { じ } 4^{\circ} \mathrm{C} \text { 時に } 18 \text { 度で } 1^{\circ} \mathrm{C} \text { 程 } \\
\text { 度、30度では2 } 2^{\circ} \mathrm{C} \text { 程度に } \\
\text { なった }\end{array}$ & $\begin{array}{l}\text { 二重 } \\
\text { 床に } \\
\text { 漏気 } \\
\text { 防止 } \\
\text { 処置 }\end{array}$ & $\begin{array}{l}\text { (1)採用した漏気防止形二 } \\
\text { 重は試作品で棈度が悪 } \\
\text { く漏気囬が多かった }\end{array}$ \\
\hline 物 & $\begin{array}{c}\text { 実 } \\
\text { 測 } \\
2\end{array}$ & $\begin{array}{l}\text { ·実測目的その他 } \\
\text { - 漏気防止制御形 } \\
\text { した。 } \\
\text { · 多少隌間風の影 }\end{array}$ & $\begin{array}{l}\text { 电測 } 1 \text { と同じ } \\
\text { 二重床を採用 } \\
\\
\text { 罡があった。 }\end{array}$ & $\begin{array}{l}\text { 旋回流形 } A \\
18.30 \text { 度 } \\
\text { 約 } 70 \% \text { 改 } \\
\text { 良形シャッタ } \\
\text { 一付 }\end{array}$ & 10 & $\underset{10}{6}$ & \begin{tabular}{|} 
設計O A值 \\
$120 \mathrm{~W} / \mathrm{m}^{\prime}$ \\
実測時は約 \\
$40 \%$ 負 \\
荷率
\end{tabular} & $\begin{array}{r}154 \\
\mathrm{~m}^{2} \\
\text { 漏気率 } \\
17 \sim \\
27 \%\end{array}$ & $\begin{array}{l}\text { 高熱負荷 } \\
\text { 事務空。 } \\
\text { 廊下は外 } \\
\text { 気状態 }\end{array}$ & 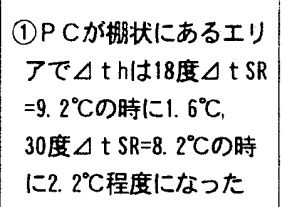 & $\begin{array}{l}\text { 漏気 } \\
\text { 防止 } \\
\text { 二重 } \\
\text { 床 }\end{array}$ & 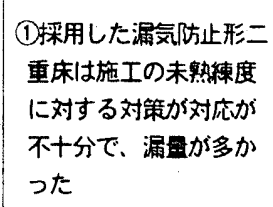 \\
\hline の & $\mid$\begin{tabular}{c|} 
果 \\
測 \\
3
\end{tabular} & $\begin{array}{l}\text { ·実測目的、漏気 } \\
\text { 重床、その他は我 } \\
\text { ·大空間の機能的 } \\
\text { 例 }\end{array}$ & $\begin{array}{l}\text { 汸止制御形二 } \\
\text { 測 } 2 \text { と同じ. } \\
\text { 事務室の奏測 }\end{array}$ & $\begin{array}{l}\text { 旋回流形 } A \\
18.30 \text { 度 } \\
\text { 約 } 70 \% \text { に改 } \\
\text { 良形シャッタ } \\
\text { 一付 }\end{array}$ & 10 & $\begin{array}{c}6 \\
9\end{array}$ & $\begin{array}{c}\text { 設計 } 0 \text { A值 } \\
100 \mathrm{~W} / \mathrm{m}^{\circ} \\
\text { 実測時は約 } \\
30 \sim \\
100 \%\end{array}$ & $\begin{array}{r}4600 \mathrm{~m}^{2} \\
\text { /陼 } \\
\text { 漏気率 } \\
5 \sim \\
50 \%\end{array}$ & $\begin{array}{l}\text { 大空間の } \\
\text { 高熱負荷 } \\
\text { 事務室 }\end{array}$ & 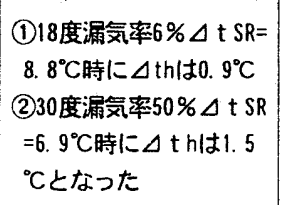 & $\mid \begin{array}{l}\text { 漏気 } \\
\text { 防止 } \\
\text { 二重 } \\
\text { 床 }\end{array}$ & $\begin{array}{l}\text { (1)漏気防止形二重床はま } \\
\text { だ施工棈度に改良の必 } \\
\text { 要珄あり }\end{array}$ \\
\hline 測 & $\begin{array}{l}\text { 実 } \\
\text { 測 } \\
4\end{array}$ & $\begin{array}{l}\text { ·実測目的、漏気 } \\
\text { 重床、その他は央 } \\
\text { ·大空間の機能的 } \\
\text { 例 }\end{array}$ & $\begin{array}{l}\text { 汸止制御形二 } \\
\text { 測 } 2 \text { と同じ. } \\
\text { 事務室の実測 }\end{array}$ & \begin{tabular}{r|}
18 度 \\
内旋回流形 $\mathrm{A}$ \\
内孫統は 1 \\
$00 \%$ 改良形 \\
シャッター付
\end{tabular} & 10 & $\begin{array}{ll}8 \\
\sim \\
1 & 0\end{array}$ & $\begin{array}{c}\text { 設計OA值 } \\
50 \mathrm{~W} / \mathrm{m}^{\prime} \\
\text { 実測時は約 } \\
50 \sim \\
100 \%\end{array}$ & $\begin{array}{r}1000 \mathrm{~m} \\
\text { /階 } \\
\text { 漏気率 } \\
8 \sim \\
15 \%\end{array}$ & $\begin{array}{l}\text { 大空間の } \\
\text { 中熱負荷 } \\
\text { 䨘務室 }\end{array}$ & $\begin{array}{l}\text { (1) } 18 \text { 度漏気率 } 9 \% \Delta \mathrm{t} \mathrm{SR=} \\
8.8^{\circ} \mathrm{C} \text { 時に } \Delta \mathrm{th} \text { h }{ }^{\circ} \mathrm{C} \text { 弱 } \\
\text { になった }\end{array}$ & $\left|\begin{array}{l}\text { 漏気 } \\
\text { 防止 } \\
\text { 二重 } \\
\text { 床 }\end{array}\right|$ & 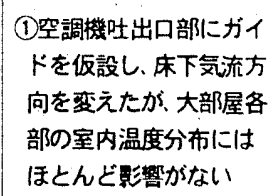 \\
\hline
\end{tabular}


尚、杭出し口Aの溝形旋回流形式は、吹出し角度によってその 気流形状が素直に変わって理解し易いことや、前述のように気流形 状や吹出し空気量、意匠性などが総合的に良好と判断されたことも あり、以降はこれを基本にして、最適な吹出し角度を確定すること に重点をおいて進めることにした。

\section{1 ．3 吹出し気流到達高さと垂直温度分布}

実測 1 と実験 5 で、室内熱負荷や吹出し風量、温度、その他の条 件を同じにして、床吹出しロのみを変えた垂直温度分布の比較を行 つた。

ア）実測 1 の内部通路部分の垂直温度分布

図 4 と図 5 に実測 1 で行った図 1 の内部通路部分の垂直温度分布 を示す。

(1)床吹出し口A 30 を用いた図 4 では、 $\Delta \mathrm{th}$ h゙1. 7Cであるのに対し、 A18を用いた図 5 では0. $9^{\circ} \mathrm{C}$ となている

(2)等温線の分布からも吹出し気流が高温層を押し上げている状況の 違いがわかる

イ）実験 5 の各種床吹出しロによる垂直温度分布

図 6 に熱負荷状況や循環空気量を同じにした実験 5 の測定点（座 席位置）における各種休吹出し口による垂直温度の変動状況を示す。 吹出し角度や寸法、断面形状などの違いによる気流特性が各点の温 度に影響していることがわかる。

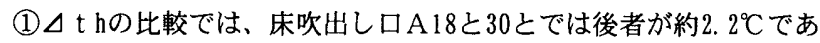
るのに対して、前者では約 $1.4^{\circ} \mathrm{C}$ になっている。同じ 30 度でも気

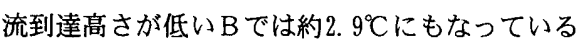

(2)A 18 を見ると相対的に $0.1 \mathrm{~m}$ と $1.7 \mathrm{~m}$ との温度差が小さく、 $1.7 \mathrm{~m}$ と2. $5 \mathrm{~m}$ との温度差が大きい良好な居住域空調が形成されている

(3)木床上0.1mの温度はA 18>A 30>B となっていて、吹出し気流の

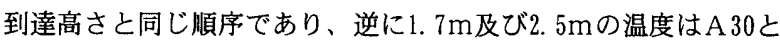
$\mathrm{B}$ はA18より上昇していて $\Delta \mathrm{th}$ 大をきくしている

(4)各高さによる温度差から判断すると、A 30では1.7mの高さが、 Bでは1. $4 \mathrm{~m}$ の高さがほぼ高温層に入っていると判断できる ア）とイ）とから、本方式においては吹出し角度などの違いが、 空調域高さに大きな影響を与えていることがわかる。

5.2 本空調方式と天井吹出し方式との比較

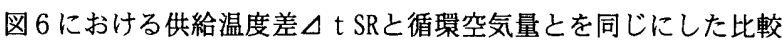
実験から（主に吹出し口A18との比較）次のことがわかる。

(1)本空調方式では吹出し温度が天井方式より約 $3^{\circ} \mathrm{C}$ 高いが、ほほ同

じ居住域温度を形成している。従来言われてきたように、天井高 2. $7 \mathrm{~m}$ 程度の事務室などでは本空調方式では吹出し温度が天井方 式より約 $3^{\circ} \mathrm{C}$ 高くてもよいことが確認できた

(2)天井吹出しの場合は気流が良く混合して、床上高さに関係なく室 内空気がほぼ $1{ }^{\circ} \mathrm{C}$ 範囲にあり、吹出し温度より約 $7.7^{\circ} \mathrm{C}$ 高い。

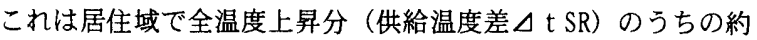
$80 \%$ 程度の上昇分となっている

(3)本空調方式では $1.7 \mathrm{~m}$ 付近では約 $5.9^{\circ} \mathrm{C}$ 高く約 $65 \%$ 程度の上昇とな っている。尚、㦿上0. $1 \mathrm{~m}$ の温度は吹出し温度より約 $4.5^{\circ} \mathrm{C}$ 高 $<\Delta$ $\mathrm{t} \mathrm{SR}$ 分の約 $50 \%$ 強となっている

(4)(2)と(3)とから、1.7mの高さまでの居住域の熱負荷率は、本空調 方式では天井方式の約 $80 \%$ 程度であることがわかる。

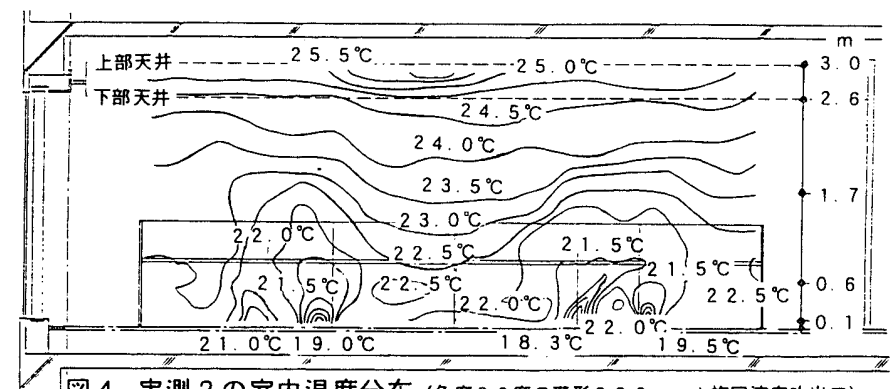

图 4. 実測 2 の室内温度分布 (角度 30 度の满形 $200 \mathrm{~mm}$ 中旋回流床吹出口) (吹出し温度 $=20.0{ }^{\circ} \mathrm{C}$ 。天井直下温度一吹出し温度 $=5.5^{\circ} \mathrm{C}$ )

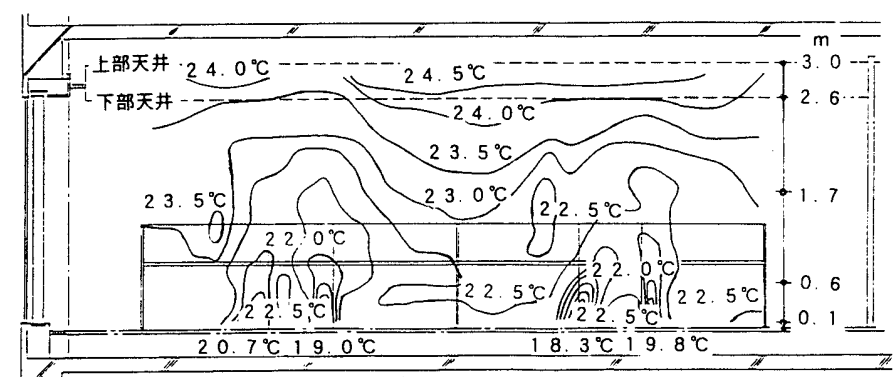

图 5.実測 2 の室内温度分布（角度18度の㴋形 $200 \mathrm{~mm}$ 旋回流床吹出口） (吹出し温度 $=19.5{ }^{\circ} \mathrm{C}$ 。天井直下温度一吹出し温度 $=5.0^{\circ} \mathrm{C}$ )

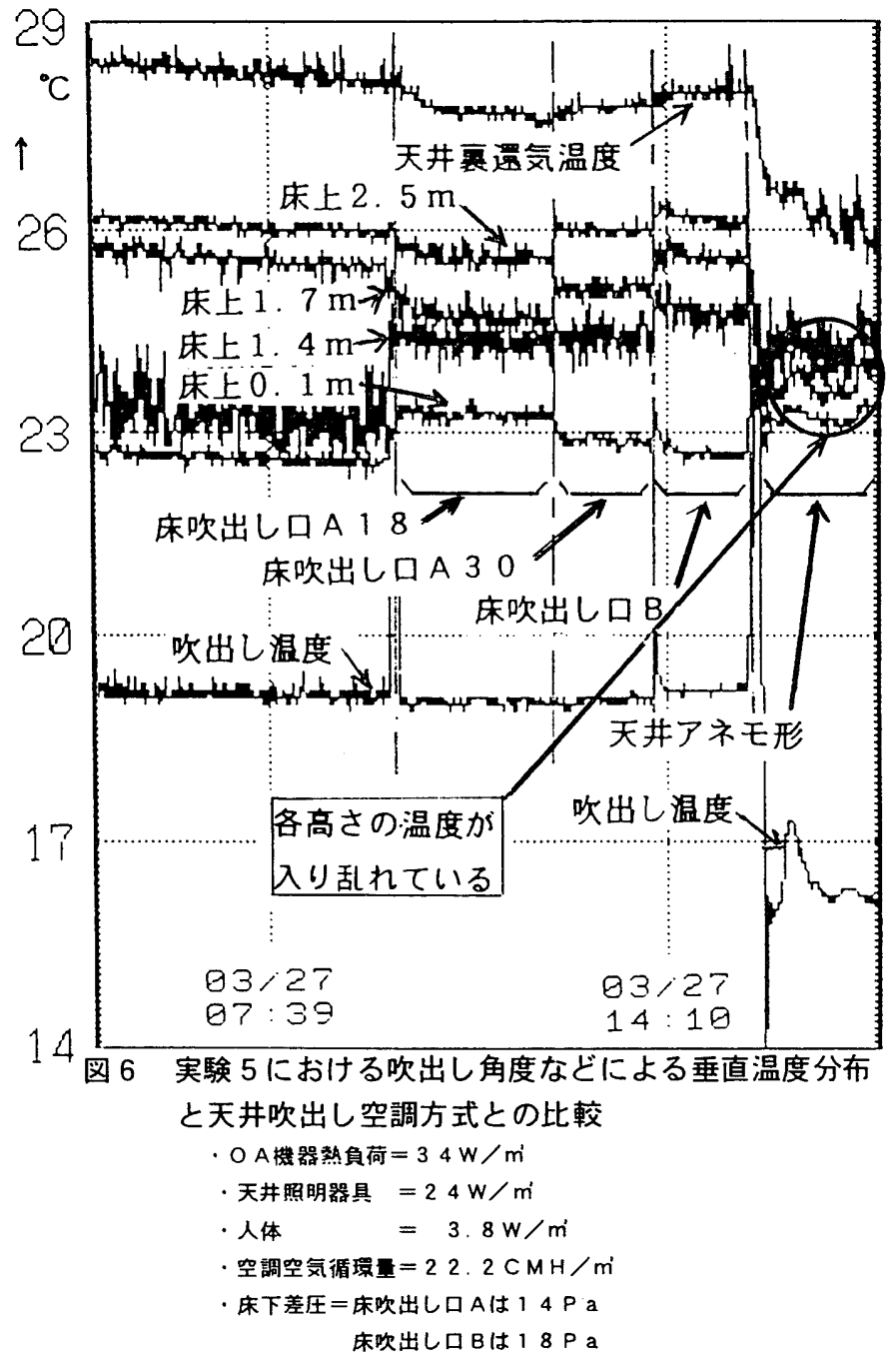




\section{6. 居住域垂直温度差に影響する 3 要因の相互関係}

\section{1 実験や実測値による垂直温度差と 3 要因のプロット}

図 7 に床吹出しロAの冷房運転時における実験および実測の結果 から、居住域垂直温度差 $\Delta \mathrm{th}$ と供給温度差 $\Delta \mathrm{t} \mathrm{SR}$ との関係を、吹出 し角度と二重床からの漏気率についてプロットした。プロットした 測定状態の室内と床下チャンバーとの差圧は、吹出し口の気流到達 高さなどの性能や、床吹出し口直上や近傍の気流速度、二重床から

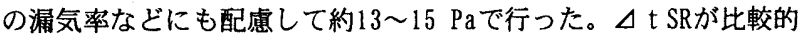
大きい場合には約14〜15 Pa、小さい場合には13〜14 Paであった。

\section{2 制御目標要因とその設定}

\subsection{1 二重床からの漏気率}

図 7 にプロットされた各点について、二重床からの漏気率は約5 〜 60\%とその幅は広い。冷房時の漏気は、基本的に床からの押出し 空調となって垂直温度差を大きくする方向にあり好ましくないが、 制御目標値は緩い方が漏気防止制御を考慮すると好ましいことがわ かっていた。

そこで漏気量がやや多い例として、図 7 で漏気率約 $25 \%$ の曲線を 角度18度の実測点である18度(1)点と18度(2)点とを結んで描いた。同 様に 30 度 $25 \%$ 曲線を 30 度の実測点である 30 度(1)と 30 度(2)とを結んで 描いた。

次に計測点が少ないが漏気率の少ない例として、漏気率 $10 \%$ の曲
線を実測点 18 度(3)から推測した18度(4)を基点として、18度 $25 \%$ 曲線 を参考に描いた。同様に、30度 $10 \%$ 曲線を実測点 30 度(3)を基点に 30 度 $25 \%$ 曲線を参考に描いた。

各 $25 \%$ 曲線と $10 \%$ 曲線の両者を比較すると、吹出し角度 18 度の床 吹出し口を用いれば、 $25 \%$ 曲線でも目標としていた $\Delta \mathrm{tSR}$ S $10^{\circ} \mathrm{C} の$ ときに $\Delta \mathrm{th}$ h⿱202C以下になること、10\%曲線の方が同じ $\Delta \mathrm{th}$ 対し $\tau \Delta \mathrm{t} \mathrm{SR}$ 約 $1.5^{\circ} \mathrm{C}$ 程度大きくできるが、二重床からの漏気率を $10 \%$ 以下とすることは非常に難しいこと、さらに $25 \%$ の実測数が多く信 頼性が高いことなどの理由から、25\%の曲線を本空調方式の基準曲 線とすることにした。

18 度 $25 \%$ 曲線や 30 度 $25 \%$ 曲線は、それぞれの実験や実測のほとん どの計測点を満たしている。

\section{2 , 2 床吹出し角度}

吹出し角度については、プロットした実測点が18度と30度以外に は20度が2点のみであったので、吹出し角度として最良と考えられる 18度と、従来から広く用いられている30度について線を描くことと した。

\section{3. 3 要因の相互の関係}

図 7 における 3 要因の相互の関係から次のことが言える。

(1)溝形 $200 \mathrm{~mm} \phi$ 旋回流形床吹出しロA 18 またはA 30 を用いた本空 調方式では、二重床からの漏気率を $25 \%$ 以下として、 $\Delta \mathrm{th}$ 与与

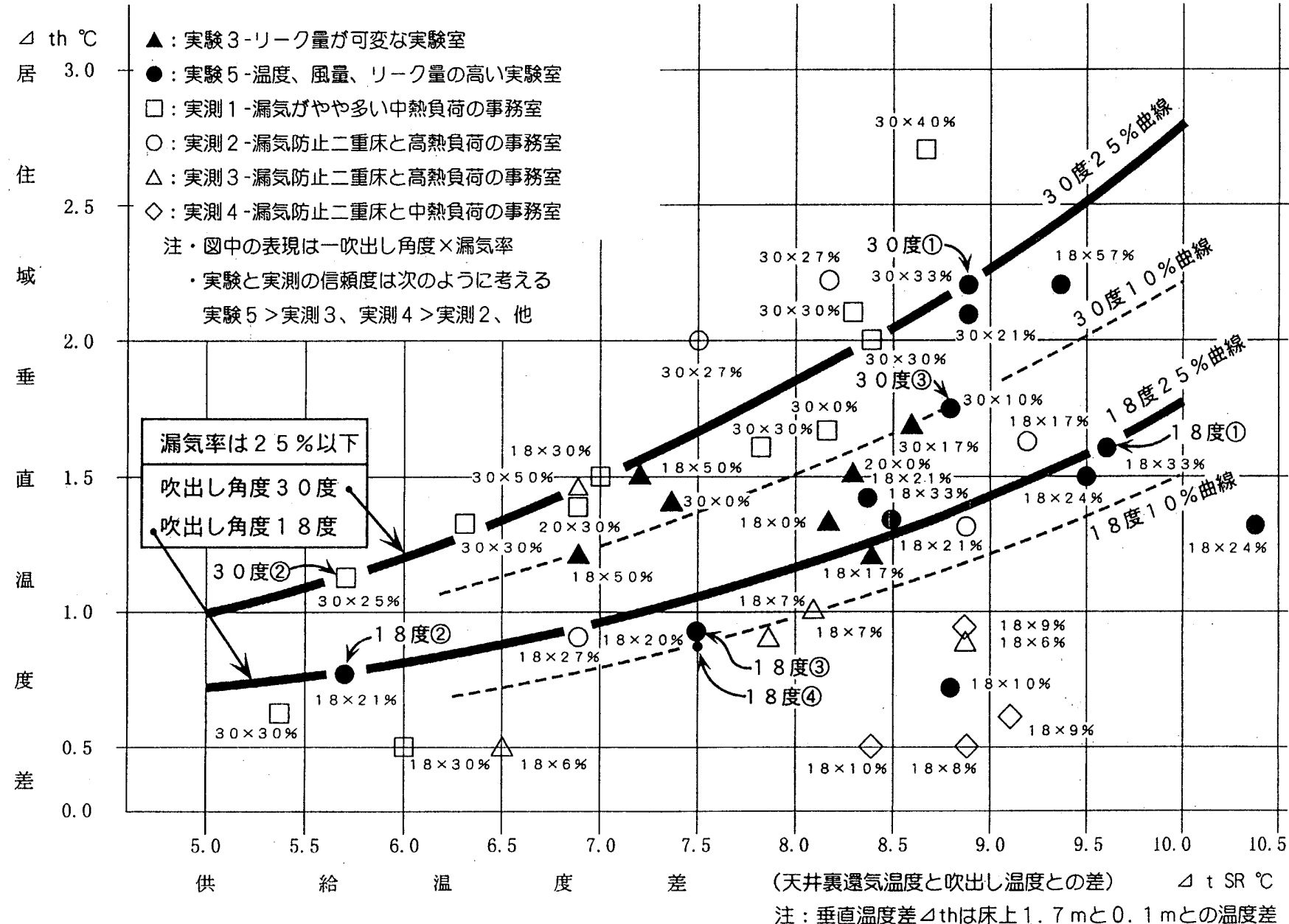

図 7. 溝形 $200 \mathrm{~mm}$ Ф旋回流形床吹出し口を用いた加圧式床吹出し居住域空調方式の 垂直温度差と吹出し角度、二重床漏気率、供給温度差との関係 
えれば（例えば2゚C以下など）、設計に必要な吹出し角度や供給 温度差 $\Delta \mathrm{tSR}$ S゙求められる

(2)供給温度差 $\Delta \mathrm{t} \mathrm{SR} 10^{\circ} \mathrm{C}$ 以下、二重床からの漏気率を $25 \%$ 以下、 吹出し角度18度の吹出しロA18を用いて、適正な運転制御を行え ば $\Delta \mathrm{th}$ は2 ${ }^{\circ} \mathrm{C}$ 以内にすることができる

同じく30度の吹出しロ $\mathrm{A} 30$ を用いれば約 $3^{\circ} \mathrm{C}$ 程度になる。

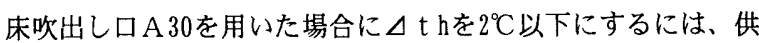
給温度差を約 $8.0^{\circ} \mathrm{C}$ 以下とする必要がある

(3)供給温度差 $\Delta \mathrm{t} \mathrm{SRが5、6} 6^{\circ} \mathrm{C}$ か ら 8 1 $10^{\circ} \mathrm{C}$ と大きくなるにつれ、 $\Delta$ $\mathrm{th}$ hよよりきくなる

\section{7．居住域における気流速度}

表 5 に実験 5 で行った実測例を示す。最適と考えられる吹出しロ A18を用い、漏気防止形二重床を用いて居住域空調を行った場合の 作業エリアに相当する部分における気流速度分布である。

床吹出し口芯から0.6mはなれた位置での最大気流速度が $0.2 \mathrm{~m} / \mathrm{s}$ になっていることから、座席位置と床吹出し口芯との必要な離隔距 離は0.6m以上となった。

通路では床吹出し口直上を通る瞬時の問題であるが、実測 4 では 床上 $0.1 \mathrm{~m}$ の気流速度は約 $1.6 \mathrm{~m} / \mathrm{s}$ 程度であった。

以上より、吹出し気流によるコールドドラフトについては問題な いと判断される。

\section{8、パーソナル制御用床吹出しロシャッタ}

市販品に付属している既製の床出しロシャッターは、その目的が 二重床下チャンバーの圧力調整用として考案されたものと考えられ るが、実際には各人がパーソナルの気流制御用として使用している (特に冬季の操作率が高い傾向にある) ${ }^{5)}$ 。

しかし、これらのシャッター機構は図 8（a ）に示すように、下 部バスケット内への空気導入用開口面積を制御するものであり、操 作（絞る）すると導入空気量は減るが、吹出し口本体の吹出し開口 面積は変わらないので吹出し速度が小さくなり、吹出し気流が所要 の高さまで到達しなくなって空調域高さが低くなってしまう。結果 として、パーソナル性が温度分布を悪化させることになっていた。 そこで、図8（b）と写真 2 に示す操作しても個々の溝形吹出し 開口からの吹出し速度が変わらないシャッターを考案した。このシ ヤッターは、床吹出し口本体の裏面に設けた8枚のシャッター羽で、 大小合わせて計32ケある吹出し口本体の溝形吹出し開口を開閉する もので、その操作は床吹出し口本体の上部から行う。各人の床上か らのシャッター操作により、「開」状態の各吹出し開口からは通常 の速度で吹出され、「閉」状態の開口からは吹出されない。シャッ ター操作の開度により1ケの瑇形開口が「開」と「閉」との中間にな る場合もあるが32ケの内の1ケであり、問題となる率ではない。

下部バスケットは従来の外蓋のみで、その空気導入用開口面積は 一定であり、シャッター操作により减少する導入空気に対する圧力 損失はむしろ低下する傾向にある。

表 6 に考案したシャッターと既製品との操作（開口率）による吹 出し気流速度の実測值を示す。考案品では吹出されている開口から の室内への吹出し気流速度はほぼ一定であり、可視化による確認で も吹出された気流の到達高さや抎散状況は全開状態とほとんど变ら
表 5. 㴖形 $200 \mathrm{~mm}$ ф旋回流形床吹出し口近傍の気流速度

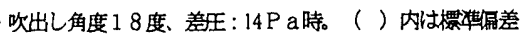
天井高は $2.7 \mathrm{~m}$

\begin{tabular}{|c|c|c|c|c|c|}
\hline \multirow{2}{*}{$\begin{array}{r}\text { 林からの商さ } \\
(\mathrm{m})\end{array}$} & 本 吹 出 & ᄂ 口 & 芯 加 & の & 雒 \\
\hline & $0.6(\mathrm{~m})$ & \multicolumn{2}{|r|}{$0.7(\mathrm{~m})$} & \multicolumn{2}{|c|}{$0.8(\mathrm{~m})$} \\
\hline 1. 7 & $0.12 \quad(0.08)$ & 0.11 & $(0.08)$ & 0.11 & $(0.08)$ \\
\hline 1. 4 & $0.20 \quad(0.10)$ & 0.17 & $(0.08)$ & 0.16 & $(0.08)$ \\
\hline 1. 1 & $0.17 \quad(0.08)$ & 0.16 & $(0.07)$ & 0.15 & $(0.09)$ \\
\hline 0.6 & $0.12(0.06)$ & 0.12 & $(0.07)$ & 0.12 & $(0.07)$ \\
\hline 0.1 & $0.09 \quad(0.05)$ & 0.07 & $(0.05)$ & 0.08 & $(0.05)$ \\
\hline
\end{tabular}

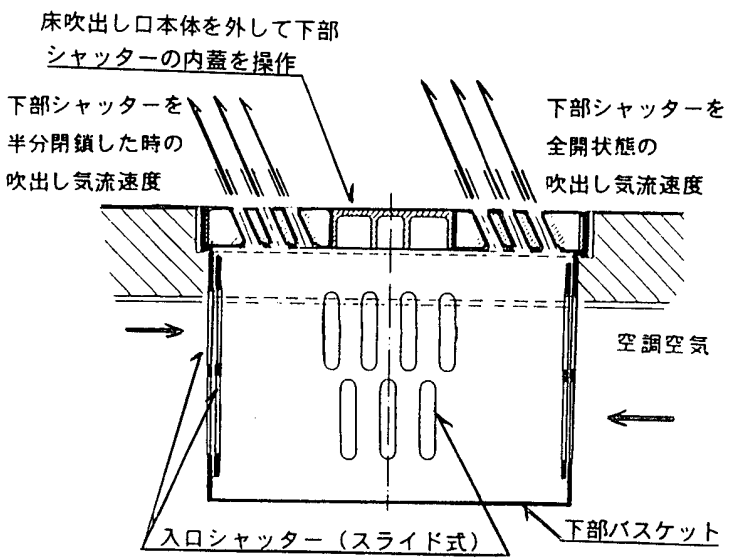

(a) 従来のシャッ夕

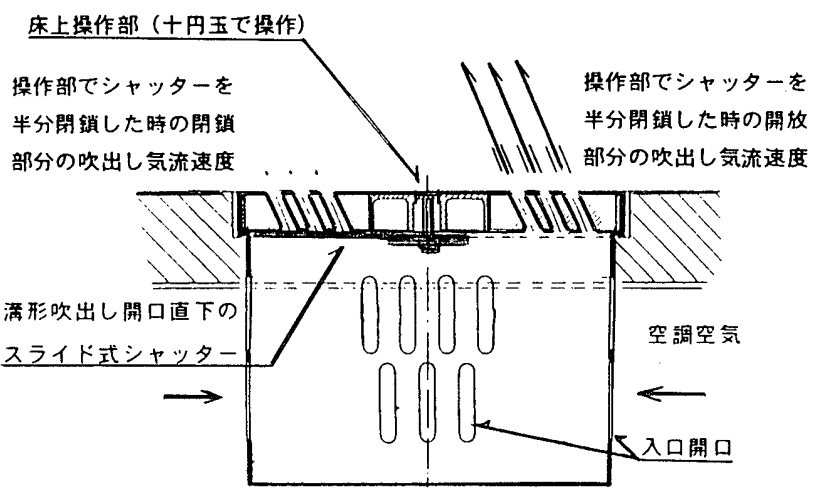

(b) 考案したシャッタ

図 8 . 床吹出しロシャッタ

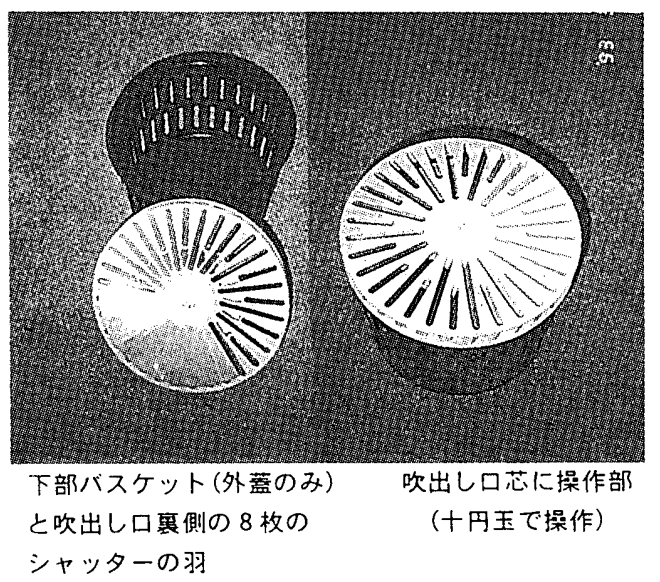

写真. $2 \cdot$ 考案した床吹出しロシャッ夕 
表6. 床吹出しロシャッター開度と吹出し気流速度 (差王：15 Pa)

\begin{tabular}{|c|c|c|c|c|c|}
\hline シャッター種別と開度 & $100 \%$ & $75 \%$ & $50 \%$ & $25 \%$ & $0 \%$ \\
\hline 考案品 $($ 図8.2) $(\mathrm{m} / \mathrm{s})$ & 4. 2 & 4. 2 & 4. 1 & 4. 1 & 0.1 \\
\hline 睡 製 品 (図8.1) (m/s) & 4. 2 & 3. 9 & 3. 6 & 1. 9 & 0.1 \\
\hline
\end{tabular}

ない。すなわち、考案品は居住者の任意なシャッター操作によって も吹出される気流速度がほとんど変わらず、到達高さや空調域高さ にほとんど影響を与えることはないものである。

\section{9. 結語}

（1）本空調方式の熱的快適性に関する重要な条件の一つは居住域 における垂直温度差であるが、それに大きく影響すると考え られる 3 つの要因を、吹出し角度、二重床からの漏気率、供 給温度差に限定し、溝形 $200 \mathrm{~mm} \phi$ 旋回流形床吹出し口を 用いる場合について、実験や実測からそれら相互の制御目標 を示した。

これにより、居住域で許容される垂直温度差（例えば、 $\mathrm{t} \mathrm{h}=2{ }^{\circ} \mathrm{C}$ など）を与えれば、二重床からの漏気率を $25 \%$ 以下を条件として、吹出し角度や供給温度差、さらに空調循 睘空気量を決めることができる

（2）吹出し気流速度については、居住域空調がなされている状態 で、最適ど考えられる吹出し角度 18 度の瑇形 $200 \mathrm{~mm} \phi$ 旋回流形床吹出し口で実測したところ、床吹出し口芯から $0.6 \mathrm{~m}$ 離れた位置での最大気流速度が $0.2 \mathrm{~m} / \mathrm{s}$ となり、 目標とする $0.8 \mathrm{~m}$ 以下となった。

休吹出し口直上の床上 $0.1 \mathrm{~m}$ の高さでも $1.6 \mathrm{~m} / \mathrm{s}$ であ り問題とならないことがわかった

（3）本空調方式の目標とした熱的快適性（ $\Delta \mathrm{t} \mathrm{h}$ が $2^{\circ} \mathrm{C}$ 以下。気 流速度が $0.2 \mathrm{~m} / \mathrm{s}$ 以下となる床吹出し口芯からの居住者 までの距離が $0.8 \mathrm{~m}$ 以下）を満たし、経済性（加圧式で、 天井方式と同等の空気循環量である $\Delta \mathrm{t} \mathrm{SR}=10^{\circ} \mathrm{C}$ ) もある 空調システムが、加圧式で吹出し角度 18 度の溝形 $200 \mathrm{~m}$ $\mathrm{m} \phi$ 旋回流形床吹出し口と漏気率を $25 \%$ 以下に制御した二 重床を用いれば、実現可能になった

(4) 满形吹出し開口の直下に設ける 8 枚羽のスライド式シャッ夕 一を考案した。これを用いれば各人が自在に操作しても吹出 される気流速度がほとんど変わらず、吹出し気流の到達高さ や空調域高さもほぼ変わらないことを明らかにした。

（5）実験 5 の天井方式との比較から、本空調方式は吹出し温度差 が約 $3{ }^{\circ} \mathrm{C}$ 小さくてもほぼ同程度の居住城温度を得られる。 さらに本空調方式では吹出し空気の居住域（休上 $1.7 \mathrm{~m}$ ) までの熱負荷率は約 $65 \%$ で、天井方式の約 $80 \%$ であった。

\section{謝辞}

本研究を行うに際して、多大な協力を戴いたお茶の水女子大学 生活 科学部 助教授田辺新一氏、当時（株）大林組 設備設計部長堸大成 氏、同現生産本部 西尾敏朗氏、同技術研究所 小宮英孝氏、原田産業 （株）䏱内哲夫氏、当時（株）不二工 宮崎清二氏、森井電業（株） 関口直也氏、他、その他多くの方々にご協力を戴きました。ここに記し て謝意を表します。

\section{あとがき}

本論文沖既発表文献 1）～6）に新たな研究結果を加えて修正した ものである。

本研究に関連した既発表文献

1) 平山昌宏、田辺新一，他：床吹出し空調方式の研究(その7) 空気調和·衛生工学会学術講演会講演論文集 (1991) pp 173 176

2 ）小宮英孝, 平山昌宏, 田辺新一、他 : 各種床吹出し口により形成さ れる室内温熱罣境評価

日本建策学大会学術講演梗概集 (1992) pp 1465 1466

3 ）平山昌宏, 小宮英孝、他 : 床吹出し空調方式の研究(その10) 日本建築学大会学術講演梗概集 (1993) pp 1385 1386

4）平山昌宏、相賀洋、他：休吹出し空調方式の研究(その14) 日本建築学大会学術講演梗概集 (1995) pp889 890

5 ）平山昌宏，武井克丞：床吹出し空調方式の研究 (その16) 日本建築学大会学術講演梗概集 (1996) pp825 826

6）平山昌宏，蜂須賀舜治、他：床吹出し空調方式の研究(その2) 日本建築学大会学術講演梗概集 (1990)pp1195 1196

参考文献

7 ）社）空気調和·衛生工学会 : 空気調和衛生工学会便覧 第12版

8 ）伊藤尚寛、中原信生、宮井信雄：軸流型吹出し口を用いた床吹出し空 調システムの室内温度分布特性

日本建築学会計画系論文報告集 (1993) pp27～35

9 ）日本建築学会環境工学・設備運営委員会 床吹出し空調システム小委 員会 : 床吹出し空調システム研究小委員会報告書 (1995. 3) PP38〜 60 $10 ）$ 後藤秀之、田辺新一、他：床吹出し空調システムのある模擬オフィ ス室内の温熱瑟境実験研究

空気調和·衛生工学会学術講演会講演諭文集 (1993) pp 457 460

11 ) 水野宏道、佐藤信孝、他：床吹出空調空間の瑟境実測 空気調和·衛生工学会学術講演会講演論文集 (1993) pp425 428

12 ）藤田尚志、鎌田元康、他 : 床吹出し空調方式における室内温度分布 日本建策学大会学術講演梗概集 (1996) pp823 824

13 ) 水野、中村、高山、他：タスク・アンビエント空調における温熱瑾境 の㭘討

空気調和・得生工学会学術講演会講演論文集 (1994) ppl 685 1688 14 ) クランツ社「床下給気システム」(1991.1)

(1997年 7 月 10 日原稿受理，1998年 2 月 3 日採用決定） 